\title{
STUDENTS, TEACHERS AND MANAGEMENT TEAMS IN BILINGUAL PROGRAMMES: SHARED PERCEPTIONS AND AREAS FOR IMPROVEMENT
}

\author{
Esther Nieto Moreno de Diezmas \\ Universidad de Castilla-La Mancha \\ Esther.Nieto@uclm.es
}

\begin{abstract}
This paper explores the shared beliefs and perceptions of students and teachers in CLIL (Content and Language Integrated Learning) programmes. Unlike in most studies, this research considers the perspectives of all categories of teachers involved when implementing CLIL, including the members of the management teams, along with CLIL programme coordinators, CLIL teachers and English teachers. A total of 114 participants from two state secondary schools located in two provinces of Castilla-La Mancha took part in the study. The instruments used for data collection were Likert type questionnaires containing between 21 and 59 questions that were supplemented with open-ended questions and interviews. Results showed various sources of tension among stakeholders, shared lay theories about bilingualism such as idealization of the native language assistant, and revealed some shortcomings in the implementation of the bilingual programmes for issues such as coordination and shortage of resources.
\end{abstract}

Keywords: CLIL, bilingual programmes, shared beliefs, teachers, students, secondary education. 


\title{
ESTUDIANTES, PROFESORES Y EQUIPOS DIRECTIVOS EN PROGRAMAS BILINGÜES: PERCEPCIONES COMPARTIDAS Y ÁREAS DE MEJORA
}

\begin{abstract}
RESUMEN. Este artículo explora las creencias y percepciones compartidas de estudiantes y profesores en programas AICLE (Aprendizaje Integrado de Contenidos y Lenguas Extranjeras). A diferencia de la mayoría de los estudios, esta investigación da voz a todas las categorías de docentes implicados en la implementación de AICLE, incluido el equipo directivo, junto con coordinadores de los programas AICLE, profesores de contenido y profesores de inglés. Un total de 114 participantes de dos escuelas secundarias públicas ubicadas en dos provincias de Castilla-La Mancha participaron en el estudio. Los instrumentos utilizados para la recopilación de datos fueron cuestionarios tipo Likert con entre 21 y 59 preguntas que se complementaron con preguntas de respuesta abierta $y$ entrevistas. Los resultados mostraron diversas tensiones, teorias compartidas sobre el bilingüismo, como la idealización del lector nativo, y revelaron algunas deficiencias en la implementación de los programas bilingües en aspectos como la coordinación y la escasez de recursos.
\end{abstract}

Palabras clave: AICLE, programas bilingües, creencias compartidas, profesorado, estudiantes, Educación Secundaria.

Received 23 February 2018

Revised version accepted 17 October 2018

\section{INTRODUCTION}

In a multilingual, globalized and inter-connected world, the need to master one or two second languages has become essential for personal, social and academic development; and a priority for institutions within the European Union, since this is conducive to constructing a cohesive Europe and promotes exchange, mobility, collaboration, employability and lifelong learning (Nieto Moreno de Diezmas 2017). In this context, European and national institutions embraced bilingual education, which was considered to be "the potential lynchpin to counter Europe's deficient language standards" (Pérez Cañado and Ráez Padilla 2015: 1), and coined their own term for it: CLIL (Content and Language Integrated Learning).

With the support of European and national institutions, CLIL programmes "are burgeoning in European school contexts" (Lasagabasbaster and Doiz 2015: 1), since bilingual education is deemed to be both "a lever for change and success in language learning" (Pérez Cañado and Ráez Padilla 2015: 1), and an "awesome innovation" in education (Tobin and Abello-Contesse 2013: 224).

The rapid expansion of CLIL "has concomitantly spawned a substantial amount of publications into the way it is playing out" (Pérez Cañado 2016: 2), and although 
STUDENTS, TEACHERS AND MANAGEMENT TEAMS IN BILINGUAL PROGRAMMES...

some authors have shown misgivings about this (Bruton 2011, 2013; Küppers and Trautmann 2013; Paran 2013) in most studies a very positive view of CLIL has been reported (Dalton Puffer 2008, 2011; Nieto Moreno de Diezmas, 2016a, 2016b, 2018a, 2018b; Ruiz de Zarobe 2011; Pérez Cañado 2012), and it is even considered to be "the ultimate opportunity to practice and improve a foreign language" (PérezVidal 2013: 59).

However, now that CLIL programmes have been running in Europe for more than a decade, it is important to move beyond the so-called "evangelical picture" of CLIL (Banegas 2011: 183) and conduct investigations that do not simply focus on "exclusively singing the praises of CLIL" (Pérez Cañado 2016: 2), but on reflecting on the strengths and weaknesses of these programmes (Hüttner, Dalton-Puffer and Smit 2013; Doiz and Lasagabaster 2017). In this way, how all the educational processes involving CLIL develop could be better understood, as well as their implications. Furthermore, areas in need of improvement in order to establish CLIL more effectively could be identified

An invaluable source of information to be studied before reaching these goals is the perceptions, beliefs and insights of all those involved in the implementation of bilingual education, so as to detect "the main needs and problems stakeholders face in their daily practice" (Pérez Cañado 2012: 330). However, further research is needed in this area (Dalton-Puffer and Smit 2013; Pérez Cañado 2012; Doiz and Lasagabaster 2017), and more information concerning all stakeholders who are committed to establishing CLIL should be gathered and analyzed.

Research into beliefs, opinions or perceptions about CLIL programmes have targeted students (Toledo, Rubio and Hermosín 2012; Coyle 2013), parents (PladevallBallester 2015; Relaño-Pastor in press) and teachers. Pena-Díaz and Porto-Requejo (2008) researched the beliefs of primary teachers about bilingual education during the preparation and training process for establishing it; Pavón and Méndez (2017) studied the beliefs of primary and secondary school English and CLIL teachers regarding cross-curricular coordination and professional development; Hüttner, Dalton-Puffer and Smit (2013), investigated the lay theories of upper secondary school teachers and learners involved in CLIL instruction and concluded that they are not always in keeping with those of experts and policy-makers; Durán-Martínez and Beltrán-Llavador (2016) looked into the views bilingual teachers at primary and secondary schools had in connection with teacher training, resources and assessment. In other studies, the thoughts university teachers have on this phenomenon are examined; for example, McDougald (2015) explored the perceptions primary, secondary and university teachers had on CLIL; Fernández-Costales and González-Riaño (2015) looked at how satisfied university teachers in bilingual programmes were, and Dafouz, Núñez, Sancho, and Foran (2007) examined the reactions university teachers and students had to CLIL. 
Although it seems that investigations conducted so far provide a comprehensive picture of this phenomenon, there is no research that gathers the different points of views of the different categories of teachers involved in establishing CLIL, i.e., members of the management teams, CLIL programme coordinators, CLIL teachers and English teachers. The members of management teams and CLIL programme coordinators are crucial to implementing the bilingual programme on a grass-roots level, but there is little information on how they perceive it or any insights they may have. Only in recent publications, has this issue been addressed. Thus, in a study conducted by Doiz and Lasagabaster (2017) the opinion the members of the management team had were voiced and compared with the beliefs teaching staff had on two controversial issues: Use of L1 and the obligatory nature of CLIL. In turn, Relaño-Pastor (2018) analyzed the narratives of the head teacher, the CLIL programme coordinator, CLIL teachers, parents, and former students of a primary school from an ethnographic perspective; and Nieto Moreno de Diezmas and Ruiz Cordero (2018) evaluated the strengths and weaknesses of bilingual programmes in secondary education in Castilla-la Mancha on the basis of the opinions teachers had, including members of the management team and CLIL programme coordinators.

To bridge this gap, in this study, student opinions have been gathered, along with the perceptions and views of the different categories of teachers involved in the bilingual programme: members of the management teams: head teachers, heads of studies and academic secretaries; CLIL programme coordinators, who are responsible for counselling and coordination within the bilingual programme (among their other duties); CLIL teachers, who teach non-linguistic subjects in English; and English teachers, who have to adapt the subject to the specific demands of the bilingual school.

In addition, and given that "shortcomings regarding CLIL programmes have not been fully addressed" (Doiz and Lasagabaster 2017: 93), this paper specifically focuses on detecting points of tension and mutual perceptions among stakeholders, and to thereby identify the main areas in need of improvement. In addition, a wide variety of practices can be found under the CLIL "umbrella" (Dalton-Puffer, Nikula and Smit 2010), and "learning environments differ not only among countries but also among regions within the same country and even among schools" (Navarro-Pablo and García-Jiménez 2018: 72). Therefore, and given that every context needs to be researched specifically (Pérez Cañado 2012), this paper provides a comprehensive overview of the setting, starting with a description of how bilingual programme regulations in the autonomous community of Castilla-La Mancha -where this study is set- were created and how they evolved. Later on, the particular circumstances of the schools where this investigation was conducted are explained. 
STUDENTS, TEACHERS AND MANAGEMENT TEAMS IN BILINGUAL PROGRAMMES...

\section{BILINGUAL PROGRAMMES IN CASTILLA-LA MANCHA}

Castilla-La Mancha is a monolingual autonomous community located in the centre of Spain. Its geographical location in the heart of the Iberian Peninsula and its relatively undeveloped industrial and tourism sectors have resulted in limited contact with foreign language speakers, and therefore, proficiency in English and French (the second languages traditionally taught in the region) has been low, as shown in international assessments such as PISA.

In this culture medium, as in the remaining Spanish autonomous communities, Castilla-La Mancha had to adapt to the European policy promoting acquisition of the mother tongue plus two second languages (European Commission 1995). To attain this objective, European and national institutions supported different lines of action, which included establishing bilingual and multilingual education (CLIL). Bilingual education in Castilla-La Mancha was launched in 1996, as a result of an agreement between the Spanish Ministry of Education (MEC) and the British Council (BC), whereby bilingual and bi-cultural education was set up at seven infant and primary schools and seven secondary schools. Nearly ten years later, in a similar vein to what has occurred in other Spanish monolingual regions, Castilla-La Mancha launched its own bilingual programme under the rubric "European Sections" (Order 07/02/2005). In European Sections at primary and secondary schools, at least 50\% of at least two school subjects had to be taught through a foreign language.

The programme started with 36 primary and secondary schools. The addition of new schools to the bilingual programme was regulated by the local administration calls annually. To be selected, schools had to comply with legal requirements, especially one regarding having enough permanent teachers holding a B2 level (CEFR) certificate, as this was the minimum qualification for teaching the required content subjects through a foreign language. All non-linguistic subjects could be taught with CLIL except religion. Therefore, CLIL subjects vary from one school to another, since these are selected by the educational establishments depending on how available CLIL teachers are. Student access to bilingual schools is on nonselective grounds and is governed by the general rules applicable to all schools, and any selection of students on the basis of their linguistic or academic merits is explicitly prohibited. In the European Sections at primary school all students are included in the bilingual programme, while at secondary school there is usually only one bilingual group per level, while the remaining students follow the regular programme.

The initial programme which began in 2005 underwent a slight alteration due to different amendments that changed the name "European Sections" to "Bilingual Sections", but this did not entail essential variations to the previous regulation. 
However, in 2014, Order 16/06/2014 introduced significant changes to the bilingual programme structure by creating a new bilingual regulation called "Linguistic Programmes". The main objectives of this regulation were ambitious: to improve the quality of the programme, and, also, to progressively spread bilingual education to all primary and secondary schools in the region. To attain these goals, the regulation enabled Linguistic Programmes (LPs) to be developed in three stages: Initiation LPs (one subject taught through a foreign language), Development LPs (two subjects taught through a foreign language), and Excellence LPs (three subjects taught through a foreign language). This standard helped CLIL spread as the entry requirements to Initiation LPs were eased (only one CLIL subject was mandatory); and, additionally, it promoted improvements to the quality of CLIL programmes by providing Excellence LPs (in which three CLIL subjects are taught in the foreign language, and at least one of the CLIL teachers needs to hold a C1 level certificate). In addition, in all LPs it was mandatory to teach the CLIL subjects through the foreign language $100 \%$ of the teaching time, thereby increasing student exposure to the target language. The objectives pursued by this regulation have proved to be effective, since the number of educational establishments with bilingual programmes has increased considerably, to such an extent that, in the academic year 2017/2018, more than 600 LPs were running in Castilla-La Mancha.

However, how bilingual education is organized, is at present undergoing amendment by Decree $47 / 2017$ and Order 27/2018, and as a result "Linguistic Programmes" will have two years to adapt to the new requirements for "Bilingual and Multilingual Projects". The new regulation abolishes the previous system of phases and replaces it with one of percentages, in which schools with bilingual or multilingual projects have to guarantee that for between 20 and $50 \%$ of the curriculum, students will be exposed to the foreign language/s. This regulation has arisen due to changes in administrative policy motivated by misgivings that the rapid expansion of bilingual schools might affect the quality of the programmes offered, in light of the fact that the administration has limited resources and therefore, bilingual schools might not be adequately equipped. In addition, the reduced exposure provided in Initiation LPs has been deemed to compromise the effectiveness of CLIL, and therefore, a higher minimum percentage of the curriculum taught in the foreign language (20\%) was set.

\section{METHOD}

\subsection{PARTICIPANTS}

The participants in this study were members of management teams, CLIL teachers, CLIL programme coordinators, English teachers and students from two 
secondary schools located in Albacete and Cuenca (Castilla-La Mancha). These schools had been previously selected by the educational authority because they were considered to represent good practice and continuity within the bilingual programme. To safeguard their identities, their original names have been replaced by the first letters of the alphabet.

School A was founded as a training centre for workers until it was transferred to the Ministry of Education in 1983 to become a Vocational Training School. In 1992 the school became a secondary school as well, and in 1996 was chosen to run a bilingual programme (English/Spanish) within the framework of the MEC/British Council agreement. Establishing this innovative programme for learning English was part of a strategy to improve its standing in the local area and to increase new student enrolments. The school is equipped with student accommodation and is attended by 700 students from the surrounding rural area, along with middle-class students from the town where the centre is located. School A provides Compulsory Secondary Education (students aged from 12 to 16 years old), Spanish Baccalaureate (16-18), and Intermediate and Advanced Vocational Training studies in tourism and catering, electricity and electronics, and maintenance services. The school has 21 years of experience in bilingual education and is currently implementing a Development LP in Compulsory Secondary Education (two subjects are taught through English). As part of the MEC/British Council agreement, school A has a language assistant and a native science teacher.

School B is attended by more than 1000 middle-class students and provides Compulsory Secondary Education, Spanish Baccalaureate, and Intermediate and Advanced Vocational Training studies in baking, pastry and confectionery, olive oil and wine, analysis and quality control (also provided in the eLearning modality), quality in the food industry and environmental chemistry. School B was a pioneer for establishing multilingual education. It is outstanding in that it has three different types of Linguistic Programmes with three foreign languages as a means of instruction: English, Italian and German. The school has been running the EnglishSpanish bilingual programme since 2006, which at present has been praised as an Excellence LP (three subjects are taught in English, and all CLIL teachers have a B2 or C1 language level). The Development LP in Italian (two CLIL subjects in Italian) has been running since 2012 and is the only bilingual programme in Spain with Italian as a language for instruction. Finally, the Initiation LP in German (one CLIL subject in German) has been running in school B since 2014. The educational authority does not provide any language assistant for the Excellence LP, as this is deemed to be a consolidated program. In contrast, the school does have Italian and German language assistants to support the LPs in their development and initiation stages respectively. 
A total of 114 participants from both secondary schools took part in the study: 72 students (55.6\% male and $44.4 \%$ female), and 42 teachers (40.5\% male and $59.5 \%$ female).

Students were enrolled in the 4 th year of secondary education (15-17-yearolds) and 26.1\% -who mainly came from School A- had already received bilingual education at primary school, while $73.9 \%$ joined the bilingual programme at secondary school. Additionally, 95.8\% of the students passed English in the final assessment and $11.1 \%$ obtained a mark of 9 or 10 out of 10 .

Teachers were split into four categories, according to the different roles they had and their responsibilities within the bilingual programme: 9 members of the management team, 2 CLIL programme coordinators, 11 English teachers and 20 CLIL teachers. The members of the management teams were: 2 head teachers, 1 academic secretary and 6 heads of studies, 55.6\% of them had a C1 level of English, and $22.2 \%$ had B2. The English level of the CLIL teachers was also high and above that required by law (B2), since $65 \%$ of them had C1 (in the CEFR); $25 \%$, had C2, and 10\%, had B2.

\subsection{INSTRUMENTS AND PROCEDURE}

To gather the data, two types of instruments were applied: surveys and interviews. For the surveys, five-point Likert scales were used: $1=$ Strongly disagree, 2 = Disagree, $3=$ Neither agree nor disagree, $4=$ Agree, and $5=$ Strongly agree. The student questionnaires included 21 questions connected to 3 areas: CLIL subjects, the subject English, and general satisfaction with the bilingual programme. The teacher questionnaires comprised 59 questions for CLIL and English teachers, 50 for management teams and 54 for CLIL programme coordinators. These questions were split into 6 research areas: the role of the management team; coordination within the programme; the bilingual culture at the school; human and material resources; planning, execution and monitoring the bilingual programme; and academic and non-academic results. The questions each area included varied in number and content in order to adapt to the situations and points of view of the different categories of teachers, as shown in table 1 .

All the participants were able to include observations and additional information in connection with all the questions in the Likert questionnaire, so that they could explain or qualify any of their answers. Additionally, the Likert questionnaire was supplemented with two open-ended questions in which all participants were given the opportunity to express their opinions more freely about the strengths and areas of the bilingual programme in need of improvement. For the purpose of carrying out more qualitative research, three interviews were carried out with 
STUDENTS, TEACHERS AND MANAGEMENT TEAMS IN BILINGUAL PROGRAMMES...

Table 1. Distribution of questions according to the areas and roles of teachers.

\begin{tabular}{|l|c|c|c|c|}
\hline & $\begin{array}{c}\text { CLIL } \\
\text { teachers }\end{array}$ & $\begin{array}{c}\text { English } \\
\text { teachers }\end{array}$ & $\begin{array}{c}\text { Management } \\
\text { teams }\end{array}$ & $\begin{array}{c}\text { CLIL } \\
\text { programme } \\
\text { coordinators }\end{array}$ \\
\hline The management team & 10 & 10 & 10 & 10 \\
\hline Coordination & 8 & 8 & 7 & 6 \\
\hline Bilingual culture at the school & 6 & 6 & 7 & 7 \\
\hline Human and material resources & 10 & 10 & 10 & 10 \\
\hline $\begin{array}{l}\text { Planning, execution and } \\
\text { monitoring }\end{array}$ & 14 & 12 & 9 & 14 \\
\hline $\begin{array}{l}\text { Academic and non-academic } \\
\text { results }\end{array}$ & 11 & 13 & 7 & 7 \\
\hline Total & 59 & 59 & 50 & 54 \\
\hline
\end{tabular}

the head teachers at schools A and B and with the CLIL programme coordinator at school A. The interviews were conducted in Spanish, recorded and transcribed.

\section{RESULTS AND DISCUSSION}

The degree of general satisfaction with the bilingual programme was high for the teachers, especially for the CLIL programme coordinators, since their average on the Likert scale was 5 points, the maximum score (=strongly agree). The average for the members of the management team was 4.67; for CLIL teachers it was 4.30 and for English teachers, 4.10, which means that the CLIL programme coordinators and the management teams displayed the most positive view on the bilingual programme, whereas English teachers, whilst still having an optimistic opinion about the programme, were the most critical group among the teachers. However, the students, in turn, seemed not to be as satisfied as the teachers, since their average on the scale was 3.82, which means that they were less sure that the bilingual programme was satisfactory, since their opinions lay between the answers "neither agree nor disagree"(=3) and "agree" (=4), on average.

The participants in the study brought up many positive outcomes the bilingual programmes had: students finish compulsory education with a very high level of English, (between B1 and B2 in the CEFR), they are fluent and use the foreign language confidently; all stakeholders, including families, are involved in the bilingual projects; the bilingual school is well viewed in the community, etc. However, this 
study does not just explore the positive aspects of these bilingual programmes, but also reflects on their shortcomings and areas in need of improvement.

Thus, once quantitative and qualitative data collected in the questionnaires and interviews were analyzed, the shared perceptions and requests from CLIL teachers, English teachers, management teams and CLIL programme coordinators were identified, along with some points of tension among the different categories of teachers (particularly regarding teachers of English). The opinions of students, in turn, helped to gain a general overview of how the bilingual programme worked.

\subsection{MUTUAL VIEWS AND SHARED PERCEPTIONS AMONG CLIL TEACHERS, ENGLISH TEACHERS, MANAGEMENT TEAMS AND CLIL PROGRAMME COORDINATORS}

CLIL and English teachers, CLIL programme coordinators and members of the management team, in general, displayed mutually positive views. All the teachers regarded the members of the management team positively, since CLIL teachers (4.40 on average), English teachers (4.36), and CLIL programme coordinators (4.50) chose between "agree" (=4) and "totally agree" (=5) when asked if the members of the management team had good knowledge of bilingual education (methodology, regulations, etc.); that the members of the management teams were regularly involved in bilingual programme activities both inside and outside the educational centre (CLIL teachers, 4.25; English teachers, 4.18), and that the members of the management team showed public support to teachers participating in the bilingual programme (CLIL teachers, 4.45; CLIL programme coordinators, 4.50; English teachers, 4.36).

Management teams, in turn, had favourable opinions about CLIL teachers, since most of them agreed or totally agreed that CLIL teachers had good knowledge of English (4.50 on average); had specific pedagogical knowledge on CLIL methodology (4.50); and were committed to the bilingual project (5.00). In addition, the members of the management team and the CLIL programme coordinators specified that the greatest asset to the programme was the CLIL teachers themselves, and stressed how committed they were to the bilingual project. Additionally, the members of the management team valued the experience of CLIL teachers very highly as well as their participation in international projects and their continuity at the school. In this respect, CLIL coordinator 1 , considered one clear advantage as having at least one permanent CLIL teacher who had been teaching at the school since 2006 and to have had few temporary teachers. The comments made by some students were in keeping with this concept, as they complained about the quality of the classes and the level of English substitute teachers had, and in this respect, 
STUDENTS, TEACHERS AND MANAGEMENT TEAMS IN BILINGUAL PROGRAMMES...

teacher continuity and commitment was deemed to be one of the most important ingredients for successfully implementing bilingual programmes.

The members of the management team also held the CLIL programme coordinators in high regard, who were perceived as being well-trained in terms of English proficiency (4.89) and CLIL methodology (4.50), that they were committed to the programme (4.33) and promoted bilingual activities (4.22). However, they were not so praising about coordination in general (3.63) and on coordination among CLIL and English teachers in particular (3.63). This perception they had was in keeping with the opinion of CLIL programme coordinator 2, who considered one of the greatest shortcomings of the programme to be precisely the lack of coordination and involvement of teachers from the English Department. Even the English teachers themselves admitted that coordination between CLIL and English teachers was not effective (3.40) and they were not very satisfied with how the bilingual programme was coordinated (3.60). In the same vein, CLIL teachers had favourable opinions on the qualities and training of the CLIL programme bilingual coordinator, but also criticized coordination in the bilingual programme. The CLIL teachers considered the CLIL programme coordinators to have good knowledge on the foreign language (4.80) and CLIL methodology (4.47), and experience in bilingual education (4.55). However, they were less certain that the CLIL programme coordinators promoted good bilingual practice (3.32) or coordinated CLIL and English teachers efficiently (3.70).

In short, data collected in this study seem to indicate there are certain points of tension between English teachers and other bilingual stakeholders, i.e., CLIL teachers and CLIL programme coordinators. Therefore, management teams and the educational authority should take note and find ways of how the English Department teachers can better participate in the bilingual programme structure, by, for example, providing them with better defined responsibilities and recognizing the potential they have for contributing to the bilingual programme. Otherwise, the bilingual programme might be squandering the potential contribution English teachers can make.

In sum, coordination is key to the smooth implementation of bilingual programmes (Pavón, Avila, Gallego, and Espejo 2015) and this issue needs more reflection. However, participants did not blame each other, but rather, the educational administration for the coordination problems and shortcomings in the project, and claimed it did not provide enough supplementary hours for effective coordination processes. In the same vein, teachers held the educational authority, and not the management team, responsible for the distribution of resources, since there was a perception that "management teams have their hands tied. And this is a shortcoming" (CLIL programme coordinator 1). 
Points of tension between teachers and the educational authority were mainly identified by analyzing the open-ended questions and interviews. The requests and discontent shown by teachers were related to three main issues: changes in educational regulations, support provided by the educational authority, and finally, the human and material resources granted.

Management teams and CLIL programme coordinators are the groups of teachers most concerned about changes in legislation, probably because they are directly responsible for implementing those changes at schools: "Here the educational system changes from one day to the next" (CLIL programme coordinator 1), and they consider legal uncertainty to be detrimental to developing the bilingual programme smoothly. In a short period of time, schools have had to adapt both to the new regulations provided by the new organic law of education, LOMCE 8/2013 (applicable to the whole of Spain), and to the new regional regulation on multilingualism which transformed the Bilingual Sections into Linguistic Programmes, (Order 16/06/2014). In addition, at the time this study was carried out, Decree 47/2017 was being prepared, which changed Linguistic Programmes into Bilingual Projects and replaced the system of phases in the Initiation, Development and Excellence Linguistic Programmes with one of percentages. Schools with Bilingual Projects will now have to guarantee that between $30 \%$ and $50 \%$ of school time is devoted to a foreign language. Members of the management teams and CLIL programme coordinators explicitly commented that these changes to multilingual policy had a negative effect on the school atmosphere and the degree of satisfaction teachers felt.

A degree of dissatisfaction with the support received from the educational authority was detected within all groups of teachers, which was sometimes voiced in general terms: "the support of the administration could improve, that's for sure" (CLIL programme coordinator 1), "There is a lack of real support from the administration" (CLIL teacher 15); sometimes, this was expressed as specific complaints which were generally linked to the shortage of resources. This request from teachers to receive more support from their educational institutions has already been mentioned in previous studies (Doiz, Lasagabaster and Sierra 2013).

One point of contention in connection with the need for support is the granting of native language assistants. For both schools, language assistants are crucial for developing the bilingual programme successfully. For CLIL coordinator 1 "they are very important. A very good source of resources". In addition, the member of management team 1 , mentioned that the most valuable support provided by the 
educational authority was, to be specific, the English language assistant, who was considered to be "very useful" mainly because "he or she reinforces pronunciation", revealing, incidentally, a widespread conception in which proficiency in English is linked to having a native accent and pronunciation. However, the educational authority only granted a native language assistant to school $\mathrm{A}$, as part of the MEC/ British Council agreement, while school B was denied this due to its Excellence LP. As resources are limited, the educational administration prioritizes language assistants for schools with Initiation or Development LPs, which, in theory, need more support to successfully implement CLIL. In fact, school B has one German and one Italian assistant to reinforce their Initiation and Development LPs respectively. However, School B neither accepts nor understands this policy and continues to request an English language assistant: "in the English LP we have not had a language assistant for years. The Italian and German language assistants have been very useful for the development of both LPs" (Management team 6); "We are still waiting for the English language assistant" (Management team 7). In addition, many CLIL teachers repeatedly mentioned the lack of an English language assistant when asked about the shortcomings of the programme. Some students at school B also shared the same view "I do not like that teachers are not natives" (student 57, 45).

In addition to the need for language assistants, CLIL teachers voiced a wide range of requirements as regards the resources granted by the educational administration. Thus, CLIL teachers mainly asked for a decrease in their teaching work load to compensate for the extra burden of preparing classes, selecting and adapting materials and correcting exercises in English, a language that is not their mother tongue: "we don't stop working inside and outside the school preparing classes" (CLIL teacher 7), "It would be necessary extra teaching hours to prepare the sessions" (CLIL teacher 11).

Additionally, CLIL teachers mentioned other activities they could not successfully carry out as a result of their excessive teaching work load, such as coordination among teachers, designing interdisciplinary projects inside the school, participating in European programmes and projects, and teacher training. In this respect, CLIL teachers did not so much request more linguistic training, but rather, further instruction in CLIL methodology. In fact, $70 \%$ of CLIL teachers had not received any CLIL training, and hence, there were statements such as "I need more hours for specific training about CLIL methodology" (CLIL teacher 4), "teacher training for CLIL teachers is needed" (CLIL teacher 9).

CLIL teachers also complained about the high number of students in the bilingual classes. Bilingual students are usually split into separate classes and mixed with their monolingual peers in the non-bilingual subjects, but they are grouped 
together in a single class in the subjects taught in the foreign language. As a result, in subjects taught through CLIL there are too many students per class, which affects the quality of the teaching-learning process and, specifically speaking, reduces possibilities of teacher-student interaction. In fact, some students complained about the excessive number of students in bilingual classes and criticized "the lack of listening and oral activities, particularly speaking" (student 36); "we hardly practice speaking before the exam" (student 63). The CLIL teachers had the same point of view and stated that "the bilingual groups should be more reduced in terms of number of students to adequately implement CLIL methodologies, since with 31 students, it is not possible" (CLIL teacher 12); "we need to improve the ratio of students" (CLIL teacher 17); "the number of students should be reduced in some courses" (CLIL teacher 3).

\subsection{STUDENTS PERCEPTIONS AND DEMANDS}

Students were satisfied with the bilingual programme (3.82). When they were asked what they thought the strengths of the programme to be, they had very positive views on bilingual education: "As in the bilingual subjects we speak only in English, my English level has risen exponentially and in addition, teachers have a very good level" (student 2); "we are speaking English since 1st grade, and now we understand the classes as if they were in Spanish" (student 21); "you learn English much better than the other students that are not in the bilingual programme" (student 53) "you learn words you would never learn without the bilingual programme" (student 57). In addition, according to the students, the best part of the programme, was undoubtedly the teachers: "in my opinion, teachers are very good at English" (student 7); "there are very good teachers and you learn" (student 10); "the best part is that teachers help you to adapt" (student 20) "I like the teachers" (student 32); "the teachers are awesome" (student 41), etc. Some students even mentioned the name of a particular teacher as being the best part of the programme.

In spite of being quite satisfied with the bilingual teachers, students expressed some misgivings they had and mentioned different areas in need of improvement, such as: the lack of student exchanges and participation in international programmes, the inadequacy of some bilingual materials, the qualifications some bilingual teachers had, and other issues regarding the contents and subjects.

Many students especially valued contact with foreign students and complained about the lack of student exchanges and participation in international programmes. School B had taken part in the Erasmus+ programme, but regarding this, students requested more extensive exchanges "instead of only Erasmus+ for five students" 
(student 6). In the same vein, other students asked for "more projects and exchanges, since they are very educational, but we have only done one in all our life" (student 56). This point concerns the lack of teacher motivation to organize this kind of activities. English and CLIL teachers admitted that they did not usually participate in these events and CLIL programme coordinator 1 explained there is minimal motivation to set up international links, as carrying out these kinds of actions, that are not specifically valued or acknowledged, entails a lot of extra work for teachers.

Additionally, some students were not satisfied with the materials provided in the bilingual subjects. One of the schools used a digital book and a few students did not consider this to be adequate: "the worst part is the digital book, I don't like it very much (student 9); "the digital book leaves much to be desired" (student 10); "I don't like the use of technologies and computers" (student 12), "the worst part is the organization of the digital books, as we waste a lot of time with that" (student 22); "the content has to improve, as we use the book in PDF and presentations of teachers, and the content is not very clear" (student 58).

Just as students held good teachers in high regard, they severely criticized teachers who were perceived to not have a good level of English or that did not speak English during most or all the lesson: "some teachers have not enough English proficiency to teach in English" (student 31); "teachers should speak more time in English, as many times they forget speaking in English" (student 53); "teacher x cannot speak English" (student 54).

Furthermore, some of them commented that contents were reduced or simplified in the bilingual subjects: "We should have more content, I mean, not having less content because the subject is taught in English" (student 5); "the worst part is that we don't see as much content as in the other non-bilingual classes do" (student 27); "I don't like that sometimes instead of learning about the subject we learn more English than anything else" (student 48); "I don't like that sometimes we go very slow regarding learning new things" (student 47); "the worst part is that in the bilingual subjects we are behind because they are in English" (student 51). Other students considered the bilingual programme to be too difficult and questioned whether it was worth so much effort, and some of them suggested changes to the choice of subjects: "What I don't like is that the difficult subjects are bilingual and not the easiest ones" (student 28).

\section{CONCLUSION}

This paper explores the beliefs, opinions and views students, members of the management teams, CLIL programme coordinators, CLIL teachers and English 
teachers had about the roles they play in the bilingual programme, and about its strengths and weaknesses. Data was collected from two secondary schools which were outstanding for the quality of their bilingual programmes, in terms of teacher training, continuity within the programme, and presence of bilingual teachers (School A); and continuity, number of subjects taught through English (3 subjects) and English level of the CLIL teachers (B2 and C1) (School B). Data collected in this study shed light on the shared perceptions of the different stakeholders. The different categories of teachers valued each other positively, including the members of the management teams, although they recognized some areas in need of improvement, such as coordination and participation in international programmes. However, teachers did not blame each other or the management team for these shortcomings, but rather, the educational authority that did not grant enough teaching and supplementary hours to satisfactorily carry out these activities.

Special note should be taken regarding the role English teachers had in bilingual programmes. They were the most critical group among the teachers, probably because how they might contribute and what responsibility they have in developing the bilingual programme remains unclear. This situation could hinder smooth implementation of the programme and might prevent schools from taking advantage of the important asset English teachers are.

Additionally, the teachers who needed most support from the administration were the CLIL teachers, who were usually overwhelmed by the number of students in their classes and by their teaching work load, bearing in mind that they had to make a special effort, especially in terms of class preparation. Regardless, they were motivated and committed "more than anything by own will, because the economic compensation is minimal" (CLIL programme coordinator 1), and the educational authority as well as the management teams should take this fact into consideration, since CLIL teachers seem to be both the weakest link, and the cornerstone of the bilingual programme, at the same time.

On the other hand, some lay theories of the participants about bilingualism emerged in this study. For example, findings showed native teachers, and particularly native language assistants, played an important role in the imagination of students, teachers and management teams. Native teachers or assistants were considered to be a precious resource, a sort of panacea for improving the learning process at bilingual schools. When there was no native assistant at the school -as was the case at School B- students, teachers and management teams felt that there was a gaping gap in the programme, a crucial element that was missing. However, when participants reflected on how native language assistants contributed, they merely mentioned their potential for being a model for pronunciation and accuracy (Management team 6, 7; student 45, 57) and disregarded any other pedagogical 
or methodological considerations, which could be interpreted as evidence of a process in which natives are idealized.

Other areas in need of improvement were identified, such as the need for teacher training in CLIL methodology, the need to reduce the student-teacher ratio and the teaching work load for those participating in the bilingual programme directly. Finally, some critical issues, as yet unresolved in the implementation of bilingual education, emerged in this study, such as simplifying or reducing contents, and including or excluding particular subjects within the CLIL programme. In the Castilla-La Mancha regulation on bilingual programmes, all subjects can be taught in a foreign language, except religion and, obviously, Spanish, but the jury is still out on what the best or most suitable subjects to be taught through CLIL are.

As some authors point out (Cenoz, Genesse and Gorter 2014; Pérez-Cañado 2016), after more than a decade of bilingual education, it is time to take stock and reflect on what its points of tension, requirements, needs, shortcomings and unresolved issues are, in order to promote effective CLIL practice.

\section{REFERENCES}

Banegas, D. L. 2011. "A Review of "CLIL: Content and Language Integrated Learning". Language and Education 25: 182-185.

Bruton, A. 2011. "Is CLIL so beneficial, or just selective? Re-evaluating some of the Research". System 39: 523-532.

Bruton, A. 2013. "CLIL: Some of the reasons why... and why not". System 41: 587-597.

Cenoz, J., Genesee, F. and D. Gorter. 2014. "Critical Analysis of CLIL: Taking Stock and Looking Forward". Applied Linguistics 35: 243-262.

Commission of the European Communities. 1995. White paper on education and training. Teaching and learning. Towards the Learning Society. <http://ec.europa. eu/white-papers/index_en.htm\#block_13>. (Accessed 10 February 2018).

Coyle, D. 2013. "Listening to Learners: An Investigation into 'Successful Learning' across CLIL Contexts." International Journal of Bilingual Education and Bilingualism 16: 244-266.

Dafouz, E., Núnez, B., Sancho, C. and D. Foran. 2007. "Integrating CLIL at the Tertiary Level: Teachers' and Students' Reactions". Diverse Contexts - Converging Goals: CLIL in Europe. Eds. D. Marsh and D. Wolff. Frankfurt: Peter Lang. 91-102.

Dalton-Puffer, C. 2008. "Outcomes and processes in content and language integrated learning (CLIL): Current research from Europe". Future perspectives for English language teaching. Eds. W. Delanoy and L. Volkmann. Heidelberg: Carl Winter. 139-157. 
Dalton-Puffer, C. 2011. "Content-and-language integrated learning: From practice to principles?" Annual Review of Applied Linguistics 31: 182-204.

Dalton-Puffer, C., Nikula, T. and U. Smit. 2010. "Charting policies, premises and research on content and language integrated learning". Use and Language Learning in CLIL Classrooms. Eds. C. Dalton-Puffer, T. Nikula and U. Smit. Amsterdam: John Benjamins. 1-20.

Dalton-Puffer, C. and U. Smit. 2013. "Content and Language Integrated Learning: A Research Agenda”. Language Teaching 46: 545-559.

Doiz, A. and D. Lasagabaster. 2017. "Management teams and teaching staff: do they share the same beliefs about obligatory CLIL programmes and the use of the L1?" Language and Education 31 (2): 93-109. http://doi.org/10.1080/0950 0782.2017.1290102.

Doiz, A., Lasagabaster, D. and J. M. Sierra. 2013. "Globalisation, Internationalisation, Multilingualism and Linguistic Strains in Higher Education". Studies in Higher Education 38: 1407-1421.

Durán-Martínez, R. and F. Beltrán-Llavador. 2016. "A Regional Assessment of Bilingual Programmes in Primary and Secondary Schools: the Teachers' Views". Porta Linguarum 25: 79-92.

Fernández-Costales, A. and X. A. González-Riaño. 2015. "Teacher Satisfaction Concerning the Implementation of Bilingual Programmes in a Spanish University". Porta Linguarum 23: 93-108.

Hüttner, J., Dalton-Puffer, C. and U. Smit. 2013. "The Power of Beliefs: Lay Theories and Their Influence on the Implementation of CLIL Programmes". International Journal of Bilingual Education and Bilingualism 16: 267-284.

Küppers, A. and M. Trautmann. 2013. "It Is Not CLIL that Is a Success - CLIL Students Are! Some Critical Remarks on the Current CLIL Boom". Content and Language Integrated Learning (CLIL) In Europe: Research Perspectives on Policy and Practice. Eds. S. Breibach and B. Viebrock. Bern: Peter Lang. 285-296.

Lasagabaster, D. and A. Doiz. 2015. "A Longitudinal Study on the Impact of CLIL on Affective Factors". Applied Linguistics 38 (5): 1-26. http://doi.org/10.1093/ applin/amv059.

McDougald, J. 2015. "Teachers' attitudes, perceptions and experiences in CLIL: A look at content and language". Colombian Applied Linguistics Journal 17 (1): 25-41.

Navarro Pablo, M. and E. García Jiménez. 2018. "Are CLIL Students More Motivated? An Analysis of Affective Factors and their Relation to Language Attainment". Porta Linguarum 29: 71-90. 
STUDENTS, TEACHERS AND MANAGEMENT TEAMS IN BILINGUAL PROGRAMMES...

Nieto Moreno de Diezmas, E. 2016a. "The impact of CLIL on the Acquisition of the Learning to Learn Competence in Secondary School Education in the bilingual programmes of Castilla-La Mancha”. Porta Linguarum 25: 21-34.

Nieto Moreno de Diezmas, E. 2016b. "The impact of CLIL on the acquisition of language competences and skills in L2 in primary education”. International Journal of English Studies 16 (2): 81-102.

Nieto Moreno de Diezmas, E. 2017. "Introducción”. Multiárea. Revista de Didáctica 9: 1-4.

Nieto Moreno de Diezmas, E. 2018a. "Acquisition of reading comprehension in L1 in bilingual programmes of Primary Education. A comparative study". OCNOS 17 (1): 43-54.

Nieto Moreno de Diezmas, E. 2018b. "Exploring CLIL contribution towards the acquisition of cross-curricular competences: a comparative study on digital competence development in CLIL". Revista de lingüistica y lengua aplicadas 13: $75-85$

Nieto Moreno de Diezmas, E. and B. Ruiz Cordero. 2018. "Evaluación de los programas AICLE en Castilla-La Mancha". Influencia de la política educativa de centro en la enseñanza bilingüe en España. Eds. J. L. Ortega-Martín et al. Madrid: MECD-British Council, Secretaría General Técnica, Ministerio de Educación, Cultura y Deporte. 93-104.

Paran, A. 2013. "Content and Language Integrated Learning: Panacea or Policy Borrowing Myth?" Applied Linguistics Review 4: 317-342.

Pavón, V. and M. C. Méndez. 2017. "Analysing teachers' roles regarding crosscurricular coordination in Content and Language Integrated Learning (CLIL)". Journal of English Studies 15: 235-260. http://doi.org/10.18172/jes.3227.

Pavón, V., Avila, J., Gallego, A. and R. Espejo. 2015. "Strategic and Organizational Considerations in Planning Content and Language Integrated Learning: A Study on the Coordination Between Content and Language Teachers". International Journal of Bilingual Education and Bilingualism 18: 409-425.

Pena-Díaz, C. and M. D. Porto Requejo. 2008. "Teacher beliefs in a CLIL education project". Porta Linguarum 10: 151-161.

Pérez Cañado, M. L. 2012. "CLIL Research in Europe: Past, Present and Future." International Journal of Bilingual Education and Bilingualism 15: 315-341.

Pérez Cañado, M. L. 2016. "Stopping the 'Pendulum Effect' in CLIL Research: Finding the Balance between Pollyanna and Scrooge". Applied Linguistics Review 8 (1): 79-100. https://doi.org/10.1515/applirev-2016-2001. 
Pérez Cañado, M. L. and J. Ráez Padilla. 2015. "Introduction and overview". CLIL in action: Voices from the classroom. Eds. D. Marsh, M. L. Pérez Cañado and J. Ráez Padilla. Newcastle upon Tyne: Cambridge Scholars Publishing. 1-12.

Pérez-Vidal, C. 2013. "Perspectives and Lessons from the Challenge of CLIL Experiences". Bilingual and Multilingual Education in the 21st Century. Building on Experience. Eds. C. Abello-Contesse, P. M. Chandler, M. D. LópezJiménez and R. Chacón-Beltrán. Bristol: Multilingual Matters. 59-82.

Pladevall-Ballester, E. 2015. "Exploring Primary School CLIL Perceptions in Catalonia: Students', Teachers' and Parents' Opinions and Expectations”. International Journal of Bilingual Education and Bilingualism 18: 45-59.

Relaño-Pastor, A. M. in press. "Understanding bilingualism in Castilla-La Mancha: Emotional and moral stancetaking in parental narratives". RESLA, Revista Española de Lingüística Aplicada 31 (2): 578-604.

Relaño-Pastor, A. M. 2018. "Narrative circulation, disputed transformations, and bilingual appropriations at a public school "somewhere in La Mancha". International Journal of the Sociology of Language 250. https://doi.org/10.1515/ ijsl-2017-0057.

Ruiz de Zarobe, Y. 2011. "Which language competencies benefit from CLIL? An insight into applied linguistics research". Content and foreign language integrated learning: Contributions to multilingualism in European contexts. Eds. Y. Ruiz de Zarobe, J. M. Sierra and F. Gallardo del Puerto. Bern: Peter Lang. 129-153.

Tobin, N. A. and C. Abello-Contesse. 2013. "The Use of Native Assistants as Language and Cultural Resources in Andalusia's Bilingual Schools". Bilingual and Multilingual Education in the 21st Century. Building on Experience. Eds. C. Abello-Contesse, P. M. Chandler, M. D. López-Jiménez and R. ChacónBeltrán. Bristol: Multilingual Matters. 231-255.

Toledo, I., Rubio, F. D. and M. Hermosín. 2012. "Creencias, rendimiento académico y actitudes de alumnos universitarios principiantes en un programa plurilingüe". Porta Linguarum 18: 213-229.

\section{LEGAL REFERENCES}

Decree $47 / 2017$, de 25 de julio, por el que se regula el plan integral de enseñanza de lenguas extranjeras de la comunidad autónoma de Castilla-La Mancha para etapas educativas no universitarias. [2017/9118].

LOMCE. Ley Orgánica 8/2013, de 9 de diciembre, para la mejora de la calidad educativa. 
Order 07/02/2005, de la Consejería de Educación y Ciencia, por la que se crea el Programa de Secciones Europeas en centros públicos de educación Infantil, Primaria y Secundaria de la Comunidad Autónoma de Castilla-La Mancha.

Order 16/06/2014, de la Consejería de Educación, Cultura y Deportes, por la que se regulan los programas lingüísticos de los centros de Educación Infantil y Primaria, Secundaria, Bachillerato y Formación Profesional sostenidos con fondos públicos de Castilla- La Mancha. [2014/8175].

Order 27/2018, de 8 de febrero, de la Consejería de Educación, Cultura y Deportes, por la que se regulan los proyectos bilingües y plurilingües en las enseñanzas de segundo ciclo de Educación Infantil y Primaria, Secundaria, Bachillerato y Formación Profesional de los centros educativos sostenidos con fondos públicos de la comunidad autónoma de Castilla-La Mancha. [2018/1979]. 